\title{
The Optimal Condition of Poly(I: C)-Induced Knockout of Cre Recombinase for Mx1-Cre/ Cre- loxP Mice
}

\section{Research Article}

Keywords:

Posted Date: September 30th, 2021

DOI: https://doi.org/10.21203/rs.3.rs-789451/v2

License: (9) This work is licensed under a Creative Commons Attribution 4.0 International License.

Read Full License 


\section{Abstract}

The full text of this preprint has been withdrawn by the authors due to author disagreement with the posting of the preprint. Therefore, the authors do not wish this work to be cited as a reference. Questions should be directed to the corresponding author.

\section{Full Text}

The authors have withdrawn this preprint from Research Square. 